\title{
Comparison of Seed Viability Among 42 Species Stored in a Genebank
}

\author{
Ho-Sun Lee ${ }^{\dagger}$, Young-Ah Jeon, Young-Yi Lee, Sok-Young Lee, and Yeon-Gyu Kim \\ National Agrobiodiversity Center, National Academy of Agricultural Science, RDA, Suwon 441-717, Korea
}

\begin{abstract}
This study was conducted to compare seed viability among 42 species after ten years of storage in the midterm storage complex $\left(4^{\circ} \mathrm{C}, 30-40 \% \mathrm{RH}\right)$ at the National Agrobiodiversity Center (NAC) Korean genebank maintained by the Rural Development Administration (RDA), Republic of Korea and to suggest the relative seed longevity and suitable monitoring intervals. The germination data from initial tests and after ten years of storage were compared to measure changes in viability during storage. The decline in seed viability varied greatly among seeds from $-11.5 \%$ for Triticum sp. to $80 \%$ for melon. Coriander, crowndaisy, safflower, cosmos, Chinesebellflower, waxgourd, melon, castorbean, Welch-onion, hollyhock, wild barley, and tallfescue showed significant decreases in viability of $34.2 \%, 73.4 \%, 36.5 \%, 30.0 \%, 40.2 \%, 71.3 \%, 80.0 \%$, $65.9 \%, 45.5 \%, 51.4 \%, 53.0 \%$, and $33.5 \%$, respectively. Gardenpea, soybean, perilla, onion, wild rice, Italian-ryegrass, and pepper showed a $15-30 \%$ decline in viability, while the viability of morningglory, adzukibean, maize, and Capsicum sp. decreased by $15 \%$ to $5 \%$. Chicory, radish, Chinese-cabbage, bottlegourd, watermelon, cucumber, pumpkin, Cucurbita sp., groundnut, kidneybean, clubwheat, sesame, wheat, Triticum sp., rice, barley, orchardgrass, buckwheat, and wild tomato showed changes in viability of $<5 \%$. The changes in storage viability also varied within families. The wild types of rice and barley showed rapid viability loss and presented different aspects from cultivars. Since seed viability of species, classified as index 1 or 2 , showed germination losses $>15 \%$ after ten years of storage, a viability test should be conducted with five year intervals, while species with germination loss of $<15 \%$ (in index 3 or 4 ) can be retested at ten year intervals.
\end{abstract}

Keywords : seed longevity, seed quality, monitoring interval, genebank, active collection

Genebanks are storehouses of plant genetic resources that provide raw material for improvement of crops. Genebanks play a key role in the sustainable development of agriculture, helping to increase food production and thus overcome hunger and poverty. The seeds contained in genebanks are vital or irreplaceable resources that must be conserved to provide future agricultural options in a world facing climate change and other unforeseen challenges (Rao et al., 2006).

Seed genebanks maintain genetic resources within seeds over decades or centuries. Therefore, proper seed-handling procedures are fundamental to the long-term, cost-effective and efficient conservation of plant genetic resources. The goal of genebanks is to maintain high-viability accessions for long periods. However, mortality during storage or frequent regeneration poses the risk of genetic erosion (Parzies et al., 2000).

Seed viability testing is very important to ensure that the seeds being stored are capable of producing plants when sown in the field. Indeed, seeds must have high viability at the start of storage that is maintained throughout the storage period (Baskin \& Baskin, 1988). Seed viability declines slowly at first, and then rapidly as seeds age (Roberts \& Ellis, 1982); accordingly, it is important to know when this decline occurs so that the accession can be regenerated by replacing exiting seeds with high-viability ones. The International Standards for Genebanks (FAO/ IPGRI, 1994) recommend that viability of seeds be determined before seeds are placed in the genebank and at regular intervals during storage. The first monitoring test should be conducted after ten years for seeds stored in base collections under preferred conditions $\left(-18^{\circ} \mathrm{C}\right)$ with high initial viability ( $\geq 90 \%$ germination), while seeds stored in active collections under preferred conditions $\left(4^{\circ} \mathrm{C}\right.$, $30-40 \% \mathrm{RH}$ ) should be monitored for viability after five years.

Thousands of seed viability tests have been performed

${ }^{\dagger}$ Corresponding author: (Phone) +82-31-299-1825 (E-mail) hosun83@rda.go.kr

$<$ Received 13 September, 2013; Accepted 13 November, 2013> 
after collection or regeneration of genetic resources and during conservation in genebanks. However, monitoring of all species in a genebank en bloc at five-or ten-year intervals is relatively time-consuming. Additionally, the aging rate characteristics and potential life spans of seeds vary among species (Hendry et al., 1994). Therefore, this study was conducted to predict seed longevity by comparing seed viability among 42 species held for ten years in midterm storage $\left(4^{\circ} \mathrm{C}, 30-40 \% \mathrm{RH}\right)$ and to provide guidelines for monitoring intervals of seed viability.

\section{MATERIALS AND METHODS}

\section{Seed materials}

In this study, the seeds of 42 species conserved in the mid-term storage complex maintained a $4{ }^{\circ} \mathrm{C}$ and $30-40 \%$ $\mathrm{RH}$ for ten years at the National Agrobiodiversity Center (NAC), the Rural Development Administration (RDA), Republic of Korea. The moisture content of seed materials placed into storage was controlled at $5-7 \%$ as per the regulations of the National Agrobiodiversity Center.

\section{Seed viability test}

A germination test was performed to determine the seed viability according to the standards of the International Seed Test Association (ISTA, 2005) or those of standard germination tests set by the Korean genebank (Table 1). Two replicates with 25-50 seeds per replicate were used to test germination. If seeds of species have bigger size than that of rice seeds, germination tests were carried out with 25 seeds per replicate and by 'Between paper (BP) method' using paper towel, otherwise with 50 seeds per replicate and by 'Top of paper (TP) method' using petri dish (Rao et al., 2006).

\section{Data analysis}

For seed lots that have been held for ten years at the Korean genebank, data for initial germination was extracted from the Germplasm Management System (National Agrobiodiversity Center Database). The germination data in the initial tests and after ten years of storage were compared to determine if there had been a significant drop in viability during storage. Species that showed a drop in germinability were identified by testing the null hypothesis of no difference between the two germination values. This was achieved by calculating the two-tailed probability using a t-test.

\section{RESULTS AND DISCUSSION}

\section{Variation in seed viability between species}

The viability of seeds of 42 species was tested after ten years of storage at $4^{\circ} \mathrm{C}$ and $30-40 \% \mathrm{RH}$. There was wide variation across species in the level of decline in seed viability from $-11.5 \%$ for Triticum sp. to $80 \%$ for melon (Table 2). Coriander, crowndaisy, safflower, cosmos, Chinesebellflower, waxgourd, melon, castorbean, Welch-onion, hollyhock, wild barley, and tallfescue showed significant drops $(\geq$ $30 \%$ ) in viability of $34.2 \%, 73.4 \%, 36.5 \%, 30.0 \%, 40.2 \%$, $71.3 \%, 80.0 \%, 65.9 \%, 45.5 \%, 51.4 \%, 53.0 \%$, and $33.5 \%$, respectively. Gardenpea, soybean, perilla, onion, wild rice, Italian-ryegrass, and pepper showed $15-30 \%$ declines in viability, while morningglory, adzukibean, maize, and Capsicum sp. showed decreases of 5-15\%. The remaining species, chicory, radish, Chinese-cabbage, bottlegourd, watermelon, cucumber, pumpkin, Cucurbita sp., groundnut, kidneybean, clubwheat, sesame, wheat, Triticum sp., rice, barley, orchardgrass, buckwheat, and wild tomato showed changes of $<5 \%$.

We classified species into four categories (index 1 to 4 ) according to the intensity of the decline in viability (Table 3). Twelve species were included in index 1 , which was classified as a decline of more than $30 \%$ in viability of seeds. Seven species were classified as index 2, which showed a decline 15-29\%. Twenty-three species showed relatively stable storage as indicated by declines in viability of $<15 \%$ and were categorized as index 3 to 4 .

Some plant families had characteristically short-lived (Apiaceae and Brassicaceae) or long-lived (Malvaceae and Cucurbitaceae) seeds (Walters et al., 2005). Rincker (1981) reported that seeds belonging to the Festuca genus had poor storage quality, while those belonging to the Triticum genus, tomato (Solanum lycopersicum) and corn (Zea mays) had relatively good storage quality. Similarly, in the present study, coriander (Apiaceae) and tallfescue (the Festuca genus) showed large decreases in viability. Five 
Table 1. Specific germination conditions for 42 species used as experimental materials.

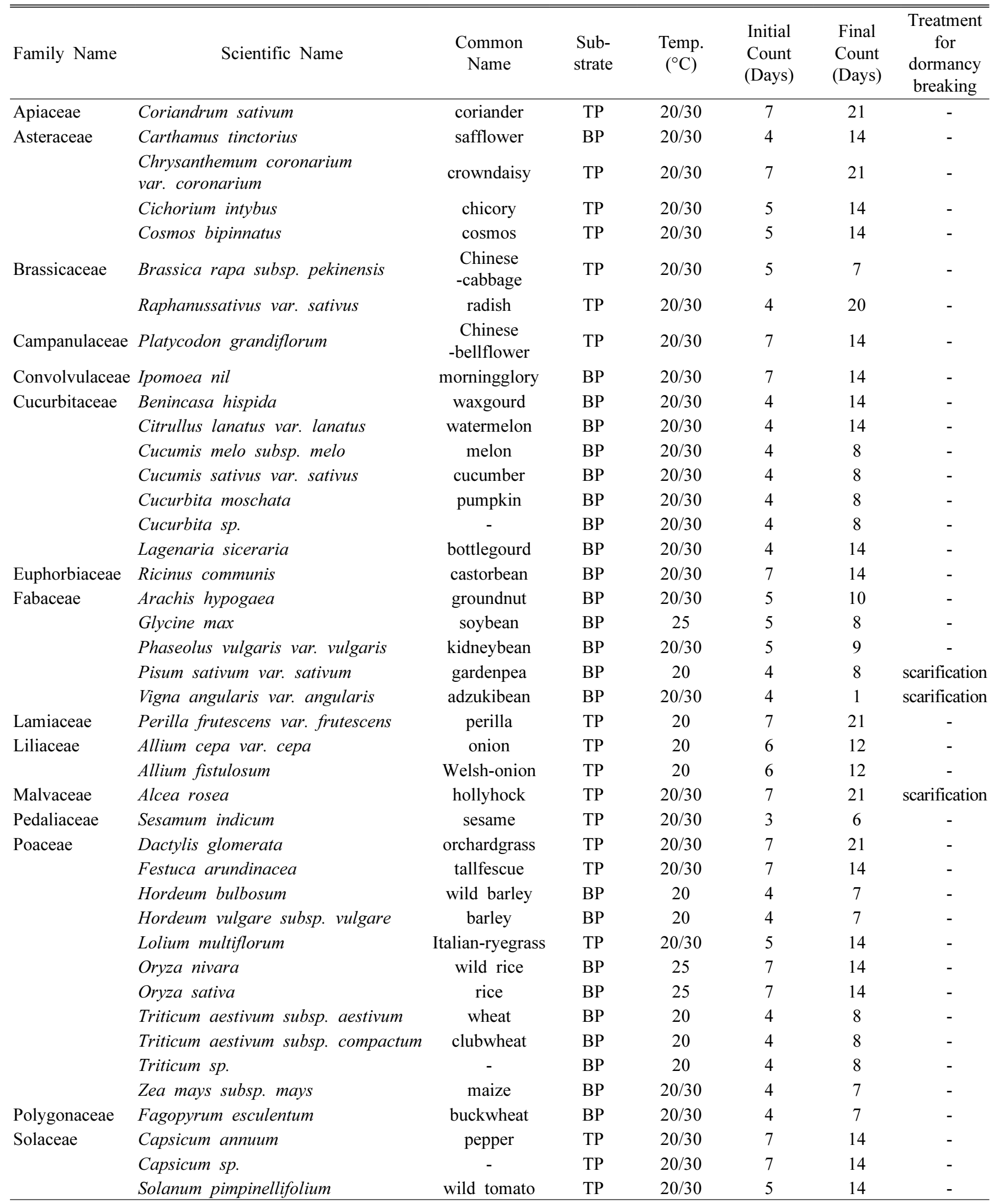


Table 2. Comparison between family, genus and species displaying a drop in seed viability during ten years of storage at $4^{\circ} \mathrm{C}$ and $30-40 \% \mathrm{RH}$ in the National Agrobiodiversity Center, Korea.

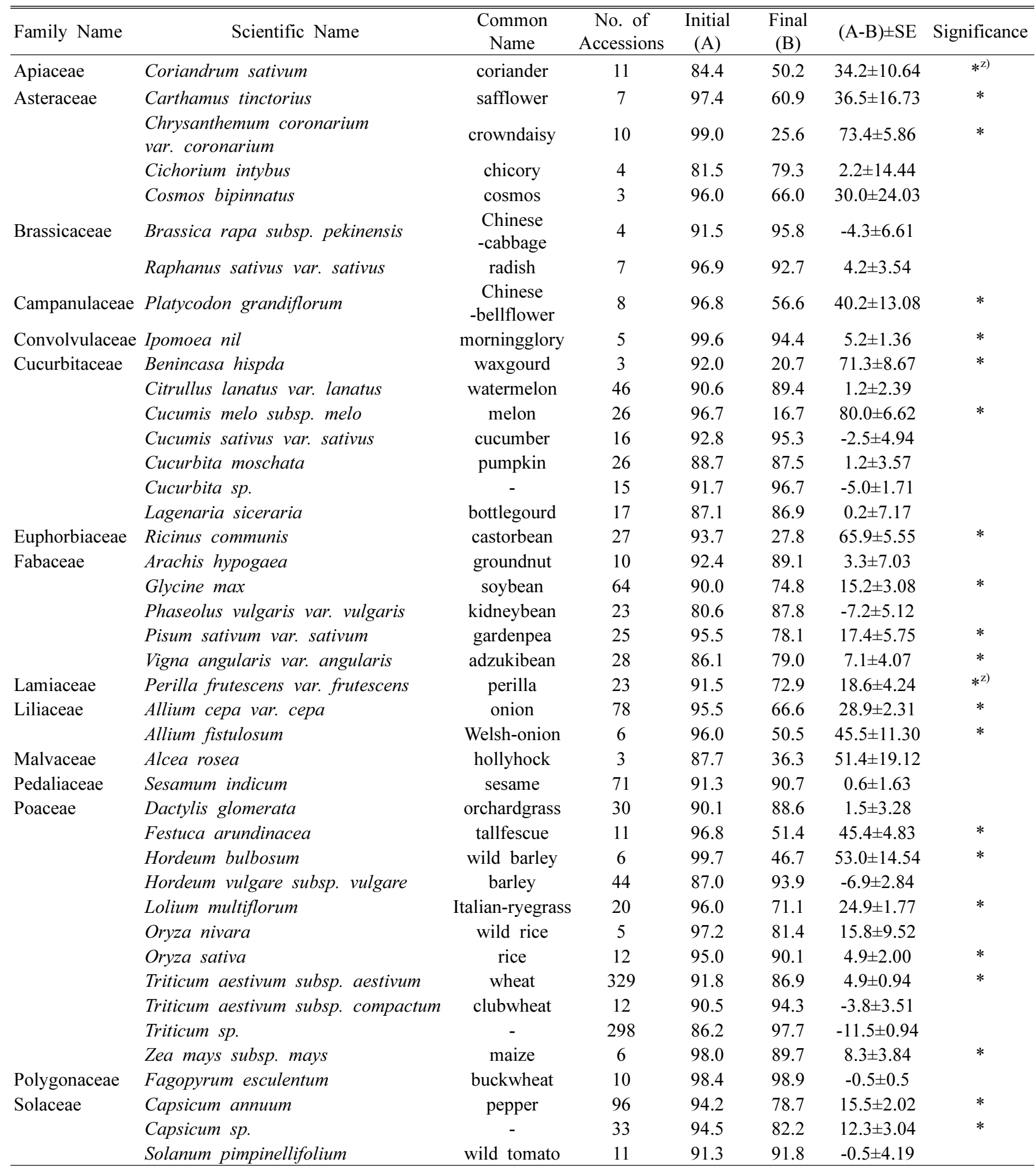

$*^{\mathrm{z})}$ : significant $(\mathrm{p}<0.05)$ 
species (watermelon, cucumber, pumpkin, Cucurbita sp., and bottlegourd) in Cucurbitaceae, three species (wheat, clubwheat, Triticum sp.) in Triticum, and wide tomato and maize maintained high viability. In contrast, hollyhock in Malvaceae showed $51.4 \%$ viability loss, indicating that it was short lived, while radish and Chinese-cabbage in Brassicaceae showed nearly constant seed viability after ten years of storage.

Seeds of some species are genetically and chemically equipped for longer storability than others under similar conditions. For example, seeds of Canna (Sivori et al., 1968), Lotus (Wester, 1973), and Lupinus (Porsild \& Harrington, 1967) have been reported to be viable even after 500 years. Other hard seeded genera reported by Harrington (1972) to be germinable after 100 years include Albizia, Cassia, and Trifolium. However, seeds of other species such as orchardgrass, soybean, lettuce, onion and rye are characteristically short-lived (Copeland \& McDonald, 2001). In this study, onion and Welsh-onion (genus Allium in family Liliaceae) showed reductions in viability of $28.9 \%$ and $45.5 \%$, respectively. However, orchardgrass showed only a small decrease in viability of $1.5 \%$.

The change in storage viability also varied within families. For example, in Asterceae, crown daisy, safflower, and cosmos were classified as index 1, but chicory as index 4 . Similarly, in Cucurbitaceae, the seed viability of waxgourd and melon decreased rapidly, whereas that of bottlegourd, watermelon, cucumber, pumpkin, and Cucurbita sp. did not. In Fabaceae, gardenpea and soybean showed an intermediate decline in seed viability, but adzukibean, groundnut, and kidneybean showed only slight and insignificant changes in seed viability. In Poaceae, wild rice, wild barley, Italian-ryegrass, and tallfescue showed large decreases in viability, while others (clubwheat, wheat, Triticum sp., rice, barley, and orchardgrass) did not. Walters et al. (2005) reported that large families such as Asteraceae, Fabaceae, Poaceae, and Solanaceae contained species with wide-ranging $\mathrm{P}_{50}$ values, that is the time for germination to decrease to half the initial value using the coefficients of Avrami viability equations (Avrami, 1941). Similarly, Probert et al. (2009) reported wide variation in $\mathrm{P}_{50}$ between families, as well as within some families, but relatively little variation in longevity among genera within those families.
It is interesting that the wild types of rice and barley showed rapid viability loss and presented different aspects with cultivars. Niedzielski et al. (2009) reported that wild rye (Secale strictum) grains aged somewhat more rapidly than cultivated rye ( $S$. cereale) grains under genebank conditions. Differences in seed longevity between cultivars and wild types of crops have been reported for diverse taxa (Walters et al., 2005; Ellis \& Hong, 2007), although there appears to be no consistent trends.

Many studies have suggested that oilseeds are short-lived (Nagel \& Börner, 2010); however, the results of the present investigation are not consistent with these results (data not shown). Walters et al. (2005) suggested that anecdotal accounts of poor storage quality of lettuce or peanut seeds have led to the widespread idea that seeds with high oil content store poorly. Indeed, the purported link between high oil content and short storage life-span has not been supported by recent analyses. Probert et al. (2009) reported that seed oil content was not correlated with $\mathrm{P}_{50}$, but that seed longevity was related to seed structure and climate of origin. Therefore, this survey showed that seed deterioration is not related to seed oil contents.

\section{Implications for monitoring of seed viability in genebank}

Table 3 presents the ranking of 42 species according to the level of viability loss after testing germination. Understanding differences in seed longevity among species is crucial to the effective management of seed conservation and collections because it influences the selection of viability retest intervals and hence regeneration or re-collection strategies (Probert et al., 2009).

Seed longevity has long been thought of as a quantitative trait that is controlled in minor ways by numerous genes scattered throughout the genome and is influenced by environmental conditions (Kochanek et al., 2010). The environmental factors influencing longevity include parental (pre-zygotic and post-zygotic) environment (Daws et al., 2004), timing of harvest (Wang et al., 2008), postharvest processing (Hay et al., 2006), and storage environment, especially, temperature and relative humidity (Roberts \& Ellis, 1989; Walters, 1998). Seed structure and climate of origin are also known genetic factors related to seed 
Table 3. Monitoring period predicted seed longevity by testing germination of 42 species based on 1,489 accession seeds stored for ten years at $4{ }^{\circ} \mathrm{C}$ and $30-40 \%$ RT.

\begin{tabular}{|c|c|c|c|c|}
\hline Index & 1 & 2 & 3 & 4 \\
\hline $\begin{array}{l}\text { Decreasing rate } \\
\text { of seed viability }\end{array}$ & $>30 \%$ & $15-30 \%$ & $5-15 \%$ & $<5 \%$ \\
\hline Crop names & $\begin{array}{c}\text { coriander } \\
\text { safflower } \\
\text { crowndaisy } \\
\text { cosmos } \\
\text { Chinese-bellflower } \\
\text { waxgourd } \\
\text { melon } \\
\text { castorbean } \\
\text { Welsh-onion } \\
\text { hollyhock } \\
\text { tallfescue } \\
\text { wild barley }\end{array}$ & $\begin{array}{c}\text { soybean } \\
\text { gardenpea } \\
\text { perilla } \\
\text { onion } \\
\text { Italian-ryegrass } \\
\text { wild rice } \\
\text { pepper }\end{array}$ & $\begin{array}{c}\text { morningglory } \\
\text { adzukibean } \\
\text { maize } \\
\text { Capsicum sp. }\end{array}$ & $\begin{array}{c}\text { chicory } \\
\text { Chinese-cabbage } \\
\text { radish } \\
\text { watermelon } \\
\text { cucumber } \\
\text { pumpkin } \\
\text { Cucurbita sp. } \\
\text { bottlegourd } \\
\text { groundnut } \\
\text { kidneybean } \\
\text { sesame } \\
\text { orchardgrass } \\
\text { barley } \\
\text { rice } \\
\text { wheat } \\
\text { clubwheat } \\
\text { Triticum sp. } \\
\text { buckwheat } \\
\text { wild tomato }\end{array}$ \\
\hline
\end{tabular}

longevity (Probert et al., 2009). Furthermore, Miura et al. (2002) detected three quantitative trait loci (QTLs) for seed longevity in rice. Genetic differences in storage potential are not limited to seeds of different species, and differences in seed storability may occur among cultivars (Kueneman, 1983; Niedzielski et al., 2009) or between genotypes of a species (Nagel et al., 2010).

Current guidelines (Rao et al., 2006) recommend that base and active collections stored according to international standards (FAO/IPGRI, 1994) be tested for viability and to determine whether the seeds have poor longevity. The FAO/IPGRI (1994) recommends that the initial germination value exceed $85 \%$ for most seeds and that regeneration should be undertaken when viability falls below $85 \%$ of the initial value. However, frequent germination tests are expensive and time-consuming and can also be a cause of gene modification. Additionally, the monitoring interval depends on species, storage environment, seed viability at the beginning of storage, and capacity of the genebank. The interval between subsequent tests should be based on experience, and may be adjusted up or down depending on the extent of viability loss observed during the first monitoring test. Although species included in index 1 or 2 should be retested at intervals of 5 years interval according to the recommendations of the ISTA, species in index 3 or 4 can be checked with a ten year interval.

\section{ACKNOWLEDGEMENTS}

This work was supported by a grant from the National Academy of Agricultural Science (PJ00855303), Rural Development Administration, Rep. of Korea.

\section{REFERENCES}

Avrami, M. 1941. Kinetics of phase change III. Granulation, phase change and microstructure. J. of Chem. Physics 9 : 177-184.

Baskin, C. C. and J. M. Baskin. 1988. Germination ecophysiology of herbaceous plant species in a temperature region. Am. J. Bot. 75 : 286-305.

Copeland, L. O. and M. B. McDonald. 2001. Principles of seed science and technology. 4th. Kluwer Academic Publishers, Massachusetts, USA. pp. 190-230. 
Daws, M. I., E. Lydall, P. Chmielarz, O. Leprince, S. Matthews, C. A. Thanos, and H. W. Pritchard. 2004. Developmental heat sum influences recalcitrant seed traits in Aesculus hippocastanum across Europe. The New Phytologist 162(1) : 157-166.

Ellis, R. H. and T. D. Hong. 2007. Quantitative response of the longevity of seed of twelve crops to temperature and moisture in hermetic storage. Seed Science and Technology 35 : 423-444.

FAO/IPGRI. 1994. Gene bank standards. Food and Agricultural Organization of the United Nations/International Plant Genetic Resources Institute, Rome, Italy. p.46.

Harrington, J. F. 1972. Seed storage and longevity. pp. 145-240 In: Seed biology. vol.III. by Kozlowski, T.T. ed. Academic Press, NY.

Hay, F., J. Klin, and R. Probert. 2006. Can a post-harvest ripening treatment extend the longevity of Rhododendron L. seeds? Scientia Horticulturae 111 : 80-83.

Hendry, G. A., F. K. Thompson, C. J. Moss, E. Edwards, and P. C. Thorpe. 1994. Seed persistence : a correlation between seed longevity in the soil and ortho-dihydroxyphenol concentration. Functional Ecology 8 : 658-664.

ISTA. 2005. International Rules for Seed Testing. International Seed Testing Association, Bassersdorf, Switzerland.

Kochanek, J., Y. M. Buckley, R. J. Probert, S. W. Adkins, and K. J. Steadman. 2010. Pre-zygotic parental environment modulates seed longevity. Austral Ecology 35 : 837-848.

Kueneman, E. A. 1983. Genetic control of seed longevity in soybeans. 1983. Crop Science $23: 5-8$.

Miura, K., S. Y. Lin, M. Yano, and T. Nagamine. 2002. Mapping quantitative trait loci controlling seed longevity in rice (Oryza sativa L.). Theoretical and Applied Genetics 104 : 981-986.

Nagel, M. and A. Börner. 2010. The longevity of crop seeds stored under ambient conditions. Seed Science Research 20 : $1-12$

Nagel, M., M. A. R. Arif, M. Rosenhauer, and A. Börner. 2010. Longevity of seeds-intraspecific differences in the Gastersleben genebank collections. Tagungsband 60. Tagung der Vereinigung der Pflanzenzüchter und Saatgutkaufleute Österreichs, 24-26 November 2009, Raumberg-Gumpenstein. pp. 179-181.
Niedzielski, M., C. Walters, W. Luczak, L. M. Hill, L. J. Wheeler, and J. Puchalski. 2009. Assessment of variation in seed longevity within rye, wheat and the intergenetic hybrid triticale. Seed Science Research 19 : 213-224.

Parzies, H. K., W. Spoor, and R. A. Ennos. 2000. Genetic diversity of barley landrace accessions (Hordeum vulgare ssp. vulgare) conserved for different lengths of time in ex situ gene banks. Heredity 84 : 476-486.

Porsild, A. E. and C. R. Harrington. 1967. Lupinus articus Wats. grown from seeds of the Pleistocene Age. Science $158: 113-114$.

Probert, R. J., M. I. Daws, and F. R. Hay. 2009. Ecological correlates of ex situ seed longevity : a comparative study on 195 species. Annals of Botany 104 : 57-69.

Rincker, C. M. 1981. Long-term subfreezing storage of forage crop seeds. Crop Science 21 : 424-427.

Rao, N. K., J. Hanson, M. E. Dulloo, K. Ghosh, D. Nowell, and M. Larinde. 2006. Manual of seed handling in genebanks. Handbooks for genebanks no. 8. Rome, Bioversity International.

Roberts, E. H. and R. H. Ellis. 1982. Physiological, ultrastructural and metabolic aspects of seed viability. pp. 465-485. In: The physiology and biochemistry of seed development, dormancy and germination. by Khan, A. A. ed. Amsterdam, Elsevier Biomedical Press.

Roberts, E. H. and R. H. Ellis. 1989. Water and seed survival. Annals of Botany $63: 39-52$.

Sivori E., F. Nakayama, and E. Cigliano. 1968. Germination of Achirs seed (Canna sp.) approximately 550 years old. Nature 219 : 1269-1270.

Walters, C. 1998. Understanding of mechanism and kinetics of seed aging. Seed Science Research 8 : 223-244.

Walters, C., L. M. Wheeler, and J. M. Grotenhuis. 2005. Longevity of seeds stored in a genebank : species characteristics. Seed Science Research $15: 1-20$.

Wang, Y., C. Mu, Y. Hou, and X. Li. 2008. Optimum harvest time of Vicia cracca in relation to high seed quality during pod development. Crop Science 48 : 709-715.

Wester, H. V. 1973. Further evidence of age of ancient viable Lotus seeds from Pulantien Deposit, Manchuria. Horticultural Science 5 : 371-377. 